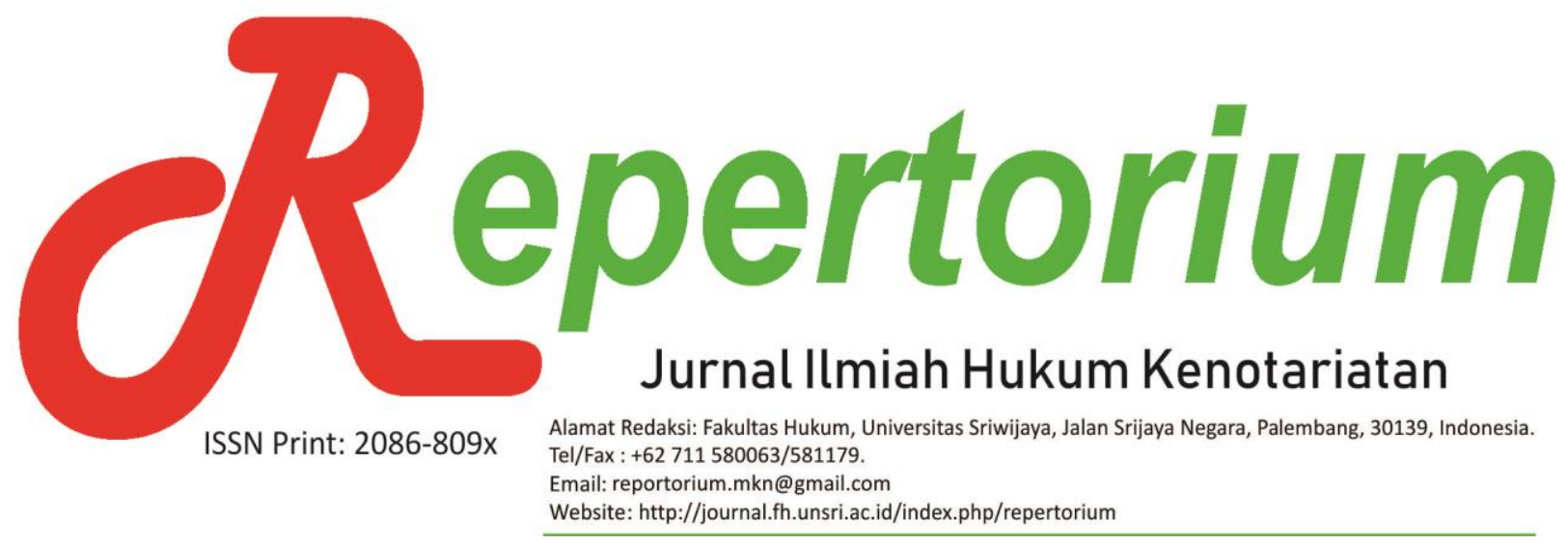

\title{
PERLINDUNGAN HUKUM ATAS LABEL HALAL PRODUK PANGAN MENURUT UNDANG-UNDANG
}

\author{
Desi Indah Sari*
}

\begin{abstract}
Abstrak: Label Halal pada produk pangan merupakan hal yang wajib untuk digunakan. Label halal sendiri dikeluarkan oleh Badan Penyelenggaraan Jaminan Produk Halal (selanjutnya disebut BPJPH), yang bekerjasama dengan kementerian dan/atau lembaga terkait seperti Lembaga Pemeriksa Halal dan Majelis Ulama Indonesia. Label termasuk dalam kategori Hak Kekayaan Intelektual yang merupakan bagian dari kekayaan intangible (kekayaan yang tidak berwujud) yang didapat dari suatu hasil pemikiran yang berupa realisasi ide atau intelektual seseorang. HKI dibagi menjadi 2 (dua) bagian yaitu: 1)Hak Cipta; 2)Hak Kekayaan Industri. Dalam pembahasan penelitian ini memfokuskan pada hak cipta dan merek. Belum ada aturan dalam hukum Islam yang mengatur secara jelas mengenai Hak Kekayaan Intelektual. Hal ini menyebabkan penulis membahas penelitian tesis yang berjudul "Perlindungan Hukum Atas Label Halal Produk Pangan Menurut Undang-Undang Tentang Hak Cipta, Undang-Undang tentang Merek dan Indikasi Geografis, dan Undang-Undang Tentang Jaminan Produk Halal". Penelitian ini merupakan penelitian hukum normatif yang menganalisis suatu keberlakuan hukum. Dilakukan dengan meneliti bahan-bahan hukum, seperti penelitian terhadap asas-asas hukum, hukum positif, aturan hukum, dan kaedah-kaedah hukum. Penelitian ini menggunakan empat metode pendekatan dalam penelitian hukum, yaitu: pendekatan perundang-undangan; pendekatan kasus; pendekatan konseptual; dan pendekatan futuristik. Pengumpulan data dalam penelitian ini adalah penelitian kepustakaan. Dilakukan dengan cara penentuan sumber data, identifikasi data, inventarisasi data, dan pengkajian data. Pengolahan Bahan Hukum dilakukan dengan cara pemeriksaan data rekonstruksi data, dan sistematisasi data. Analisis bahan hukum yang digunakan pada penelitian ini adalah analitis data kualitatif-komprehensif, dan lengkap.
\end{abstract}

Kata Kunci: Label Halal; Hak Kekayaan Intelektual; Hak Cipta, Merek.

* Magister Kenotariatan Fakultas Hukum Universitas Sriwijaya

\section{LATAR BELAKANG}

Pangan merupakan kebutuhan primer bagi setiap manusia yang harus tersedia setiap waktu, aman, bermutu, bergizi, dan dengan beragam jenisnya serta harga yang terjangkau oleh daya beli masyarakat.
Pangan dapat diperoleh oleh manusia secara langsung dari sumber alami tanpa proses dan dapat pula diperoleh dari hasil olahan yang disebut produk pangan olahan. Namun demikian, setiap pangan yang dikonsumsi oleh manusia haruslah dalam kondisi aman dan tidak membahayakan kesehatan.

Dilihat dari aspek kesehatan, pangan dinyatakan aman apabila pangan tersebut 
sehat dan bermutu. Pangan halal adalah pangan yang tidak mengandung unsur atau barang yang haram atau dilarang untuk dikonsumsi oleh umat Islam, baik yang menyangkut bahan baku pangan, bahan tambahan pangan, dan bahan penolong lainnya termasuk bahan pangan yang diolah melalui proses rekayasa genetika dan iradiasi pangan. Oleh karena itu, pangan pengelolaanya harus dilakukan sesuai dengan ketentuan hukum agama Islam. Dengan kata lain produk pangan yang aman dan sehat adalah pangan yang dapat memenuhi kebutuhan manusia dari aspek kesehatan dan kenyamanan batiniah.

Kewajiban memberikan informasi yang benar dan jujur atas setiap produk yang dihasilkan oleh produsen atau pelaku usaha merupakan salah satu kewajiban utama yang diatur dalam Undang-Undang Nomor 8 Tahun 1999 tentang Perlindungan Konsumen (Selanjutnya disebut UUPK). Berdasarkan UUPK, salah satu hak konsumen adalah berhak atas kenyamanan, keamanan, dan keselamatan dalam mengkonsumsi barang dan/atau jasa. Terjadinya perbuatan-perbuatan yang berakibat merugikan konsumen akibat penggunaan barang dan/atau jasa harus dihindari. Untuk itu, pemerintah memandang perlunya suatu perangkat hukum yang melindungi kepentingan konsumen, maka ditetapkanlah UUPK yang diharapkan dapat memperkuat penegakan hukum didalam bidang perlindungan konsumen.

Dengan demikian, pentingnya produk pangan halal tidak bisa ditawartawar apalagi melihat semakin banyaknya produk pangan kemasan yang berasal dari negara lain khususnya negara yang penduduknya mayoritas non-muslim. Oleh karena itu, adanya sertifikasi halal pada makanan dan minuman merupakan hal yang wajib. Untuk mempermudah masyarakat melihat kehalalan pada produk pangan kemasan yang dipasarkan, maka adanya label halal pada produk tersebut merupakan salah satu solusi.

Lembaga Pemeriksa Halal (LPH) menurut Undang-Undang Republik Indonesia Nomor 33 Tahun 2014 Tentang Jaminan Produk Halal (selanjutnya disebut UU-JPH), pengertian Lembaga Pemeriksa Halal kepastian hukum terhadap kehalalan suatu produk yang dibuktikan dengan sertifikasi halal. Badan Penyelenggaraan Jaminan Produk Halal (selanjutnya disebut BPJPH) mempunyai kewenangan untuk merumuskan dan menetapkan kebijakan Jaminan Produk Halal (selanjutnya disebut JPH), menetapkan norma, standar, prosedur, dan kriteria JPH, menerbitkan dan mencabut sertifikat halal dan label halal pada produk. Dalam melaksanakan wewenang BPJPH bekerja sama dengan kementerian dan/atau lembaga terkait, LPH dan MUI.

Ada beberapa contoh kasus yang telah sangat menyakiti konsumen Musim di Indonesia, yang pada akhirnya menimbulkan kerugian besar bagi produsen dan dunia usaha, yaitu: kasus isu lemak babi (1988), kasus heboh daging celeng di pasaran (2000-2002), kasus heboh yang melanda Indonesia akibat masalah keharaman penyebab masakan Ajinomoto (2001), kasus Kratingdaeng, kasus Dendeng Sapi Campur Babi di Jawa Barat dan Jawa Timur (2009), Konsumen Muslim memboikot produk yang diketahui atau dinyatakan tidak halal sehingga produsen menderita kerugian besar. 
Belajar dari kasus-kasus yang terjadi tersebut, Majelis Ulama Indonesia (selanjutnya disebut MUI) sangat berperan untuk menentramkan umat Islam dalam masalah kehalalan produk pangan dengan cara mendirikan Lembaga Pengkajian Pangan, Obat - obatan dan kosmetika Majelis Ulama Indonesia (selanjutnya disebut LPPOMMUI) yang bertugas untuk melakukan pekajian kehalalan produk pangan, obat dan kosmetika. Sebagai upaya untuk memberikan kepastian hukum mengenai kehalalan produk pangan. Baik dari sisi kesehatan dan dari sisi agama Islam yakni halal atau boleh dan baik untuk dikonsumsi bagi umat Muslim khususnya di wilayah Indonesia. Selain itu, memberikan rekomendasi, merumuskan ketentuan dan bimbingan kepada masyarakat yang berupa fatwa. Salah satu fatwa yang dikeluarkan oleh Majelis Ulama Indonesia yaitu Fatwa Nomor 4 Tahun 2013 tentang Pedoman Fatwa Produk Halal. Setelah LPPOMMUI melakukan pengkajian laboratorium mengenai produk tersebut, maka diteruskan oleh BPJPH dengan mengeluarkan Sertifikat Halal suatu produk pangan.

Hak Cipta disebut sebagai suatu hak yang memiliki nilai-nilai moral, praktis dan ekonomis. Dari sisi ekonomi Hak Cipta diartikan sebagai aset. Aset tersebut berupa aset tidak berwujud (intangable assets). Dengan memahami Hak Cipta sebagai aset tidak berwujud, maka Hak Cipta diperlakukan sama dengan aset lainnya, seperti aset berwujud (tangiable assets). Sedangkan Merek adalah tanda yang dapat ditampilkan secara grafis berupa gambar, logo, nama, kata, huruf, angka, susunan warna, dalam bentuk 2 (dua) dimensi dan/atau 3 (tiga) dimensi, suara, hologram, atau kombinasi dari 2 (dua) atau lebih unsur tersebut untuk membedakan barang dan/atau jasa yang diproduksi oleh orang atau badan hukum dalam kegiatan perdagangan barang dan/atau jasa.

Karena Islam tidak mengatur secara jelas mengenai HKI. Sehingga para ulama menganggap perlu dibahas mengenai peraturan yang melindungi HKI. Dalam konfrensi negara-negara Islam, pada forum Neenteenth Islamic Conference Foreign Ministers di Kairo yang berlangsung tanggal 31 Juli - 05 Agustus 1990 mengatakan bahwa Hak Kekayaan Intelektual (HKI) merupakan salah satu hak asasi manusia dalam Islam.

Dari berbagai macam hak yang termasuk dalam HKI, dalam penelitian ini akan memfokuskan pada label halal yang diterbitkan BPJPH. Dari fokus penelitian tersebut akan menimbulkan pertanyaan apakah label halal yang diterbitkan oleh BPJPH telah terdaftar di Direktorat Hak Kekayaan Intelektual (selanjutnya disebut Dirjen HKI)? Apakah label halal tersebut dilindungi oleh Kekayaan Intelektual.

Berdasarkan latar belakang dan uraian tersebut diatas, maka permasalahan yang akan diteliti oleh penulis yaitu sebagai berikut:

Apakah label halal yang diterbitkan oleh Badan Penyelenggara Jaminan Produk Halal (BPJPH) dalam produk pangan dilindungi oleh Undang - Undang Nomor 28 Tahun 2014 tentang Hak Cipta dan Undang - Undang Nomor 20 Tahun 2016 tentang Merek dan Indikasi Geografis ?

Bagaimana karakteristik label halal yang seharusnya digunakan oleh produk pangan yang bersertifikat halal?

Bagaimana peran Badan Penyelenggara Jaminan Produk Halal (BPJPH) apabila terjadi pemalsuan atau pelanggaran 
terhadap label halal yang digunakan pada produk pangan yang tidak melalui sertifikasi halal di Indonesia?

\section{METODE}

Berdasarkan hal tersebut, maka konsep dan teori-teori yang dapat digunakan dalam penulisan tesis ini adalah teori kepastian hukum, teori perlindungan hukum dan teori maslahah mursalah.

\section{Teori Kepastian Hukum}

Kepastian memiliki arti ketentuan/ketetapan, sedangkan jika kata kepastian digabungkan dengan kata hukum, maka menjadi kepastian hukum, yang memiliki arti "perangkat hukum suatu negara yang mampu menjamin hak dan kewajiban setiap warga negara".

Sehingga dengan adanya label halal dalam suatu produk pangan maka akan memberikan jaminan kepastian hukum terhadap suatu produk pangan tersebut. Karena kepastian hukum terhadap label suatu produk pangan memberikan keyakinan pada konsumen khususnya yang beragama Islam, bahwa produk pangan tersebut halal untuk di konsumsi. Sehingga dapat menjamin dan memberikan kepatian hukum bagi konsumen.

\section{Teori Perlindungan Hukum}

Nico Kansil menjelaskan teori yang mendasari perlindungan hukum terhadap Kekayaan Intelektual, yaitu:

Teori Reward, bahwa pencipta di bidang ilmu pengetahuan, seni dan sastra, serta penemu di bidang teknologi baru yang mengandung langkah inovatif serta dapat diterapkan dalam industri, diberikan suatu penghargaan dan pengakuan serta perlindungan atas keberhasilan upayanya dalam melahirkan ciptaan baru itu;

Teori Recovery, bahwa atas usaha dari pencipta dan penemu yang telah mengeluarkan tenaga, pikiran, waktu dan biaya yang tidak sedikit jumlahnya, kepadanya diberikan hak eksklusif untuk mengeksploitasi KI guna meraih kembali yang telah dikeluarkannya;

Teori Incentif, bahwa insentif diberikan untuk merangsang kreativitas dan upaya menciptakan karya-karya baru di bidang teknologi;

Teori Public Benefit, bahwa KI merupakan suatu alat untuk meraih dan mengembangkan ekonomi.

Sehingga ketentuan mengenai perlindungan konsumen ini (sebenarnya) telah tercantum dalam pembukaan Undang - Undang Dasar 1945 alinea IV yang menyebutkan bahwa Negara Indonesia melindungi segenap bangsa Indonesia dan seluruh tumpah darah Indonesia. Oleh karena itu, hadirnya Undang - Undang Jaminan Produk Halal merepresentasikan tanggungjawab negara, khususnya terhadap umat Islam, untuk melindungi dan memberikan rasa tenang dan aman dalam mengkonsumsi/menggunakan produk pangan yang sesuai syari'at yakni halal dan thoyib.

\section{Teori Maslahah Mursalah}

Menurut bahasa, kata Maslahah dari bahasa arab: Al - Maslahah, dan telah dibakukan ke dalam bahasa Indonesia menjadi kata maslahah, selanjutnya (juga) digunakan kata maslahah saja yang berarti manfaat atau sesuatu pekerjaan yang mengandung manfaat. Atau sesuatu mendatakan kebaikan atau membawa kemanfaatan dan/atau menolak kerusakan. Menurut 
bahasa aslinya, kata maslahah mursalah berasal dari kata saluha, yasluh, salahan; artinya sesuatu yang baik, patut, dan bermanfaat. Sedangkan kata Mursalah artinya terlepas bebas, tidak terikat dengan dalil agama (al-Qur'an dan al-Hadits) yang membolehkan atau melarangnya.

Dengan adanya label halal memberikan manfaat kepada masyarakat khususnya bagi umat muslim, sehingga masyarakat dapat membedakan mana produk pangan yang dapat dikonsumsi dan mana produk pangan yang tidak dapat dikonsumsi. Maka setiap produk pangan membuat kebaikan pada masyarakat, nyaman dan tidak ada keraguan pada konsumen.

Berdasarkan perumusan masalah dan tujuan penelitian, maka jenis penelitian yang digunakan oleh penulis dalam penulisan tesis ini dengan menggunakan tipe penelitian hukum Normatif. Penelitian Hukum Normatif adalah penelitian hukum kepustakaan. Penelitian Hukum Normatif menurut Jhonny Ibrahim adalah suatu prosedur penelitian ilmiah untuk menemukan kebenaran berdasarkan logika keilmuan dipandang dari sisi normatifnya.

\section{ANALISIS DAN DISKUSI}

Sejarah Singkat Label Halal di Indonesia Sertifikat Halal yang dikeluarkan oleh Majelis Ulama Indonesia (MUI) untuk setiap produk makanan dan minuman yang dijual kepada masyarakat sudah merupakan jaminan, sehingga di masyarakat tidak timbul kecurigaan dan tanda tanya terhadap kandungannya. Sertifikasi halal mutlak dibutuhkan untuk menghilangkan keraguan masyarakat akan kemungkinan adanya bahan baku, bahan tambahan atau bahan penolong yang tidak halal dalam suatu produk yang dijual.

Untuk menjamin kehalalan suatu produk yang telah mendapat sertifikat halal, selain menunjuk Auditor Internal disetiap perusahaan yang bertugas mengawasi kehalalan produknya, MUI menetapkan dan menekankan bahwa jika sewaktu-waktu ternyata diketahui produk - produk tersebut mengandung unsur - unsur barang haram (najis), MUI berhak mencabut sertifikat halal produk bersangkutan. Disamping itu, setiap produk yang telah mendapat sertifikat halal diharuskan pula memperbaharui atau memperpanjang sertifikat halalnya setiap dua tahun, dengan prosedur dan mekanisme yang sama. Jika setelah dua tahun terhitung sejak berlakunya sertifikat halal, perusahaan yang bersangkutan tidak mengajukan permohonan (perpanjangan) sertifikat halal, perusahaan itu dipandang tidak lagi berhak atas sertifikat halal dan kehalalan produk produknya di luar tanggung jawab MUI.

Sertifikasi halal dan labelisasi halal merupakan dua kegiatan yang berbeda tetapi mempunyai keterkaitan satu sama lain. Sertifikasi halal dapat didefinisikan sebagai suatu kegiatan pengujian secara sistematik untuk mengetahui apakah suatu barang yang diproduksi suatu perusahaan telah memenuhi ketentuan halal. Hasil dari kegiatan sertifikasi halal adalah diterbitkannya sertifikat halal apabila produk yang dimaksudkan telah memenuhi ketentuan sebagai produk halal. Sertifikasi halal dilakukan oleh lembaga yang mempunyai otoritas untuk melaksanakannya. Tujuan akhir dari Sertifikasi halal dan labelisasi halal merupakan dua kegiatan yang berbeda 
tetapi mempunyai keterkaitan satu sama lain.

Labelisasi halal adalah pencantuman tulisan atau pernyataan halal pada kemasan produk untuk menunjukkan bahwa produk yang dimaksud berstatus sebagai produk halal. Di Indonesia lembaga yang otoritatif melaksanakan Sertifikasi Halal adalah Majelis Ulama Indonesia (MUI) yang secara teknis ditangani oleh Lembaga Pengkajian Pangan Obat-obatan, dan Kosmetika (LPPOM). Sedangkan kegiatan labelisasi halal dikelola oleh Badan Pengawas Obat dan Makanan (Badan POM).

Pada tahun 2014, pemerintah menerbitkan Undang-Undang Nomor 33 Tahun 2014 tentang Jaminan Produk Halal mengatur kewenangan penerbitan sertifikat halal oleh pemerintah dalam hal ini Kementerian Agama. Sertifikasi halal yang diatur dalam Undang-Undang JPH kurang pas apabila ditafsirkan seolah negara mencampuri wilayah agama. Penetapan fatwa halal tetap menjadi otoritas MUI. Kewenangan administratif penerbitan sertifikat halal yang dialihkan kepada Badan Penyelenggaraan Jaminan Produk Halal (selanjutnya disebut BPJPH).

Setelah beroperasinya BPJPH, peran dan kewenangan MUI tetap penting dan strategis yaitu memberikan fatwa penetapan kehalalan suatu produk yang kemudian disampaikan kepada BPJPH sebagai dasar untuk penerbitan sertifikat halal. Sertifikat halal yang dikeluarkan oleh MUI selama ini tetap berlaku sampai jangka waktunya habis. Sinergi dan kerjasama BPJPH dengan MUI antara lain dalam hal Sertifikasi Auditor Syariah, Penetapan Kehalalan Produk, dan Akreditasi Lembaga Pemeriksa Halal (selanjutnya disebut LPH).
Label halal yang diterbitkan oleh Badan Penyelenggara Jaminan Produk Halal terhadap produk pangan dilindungi oleh Hak Kekayaan Intelektual khususnya Undang - Undang Nomor 28 Tahun 2014 tentang Hak Cipta dan Undang - Undang Nomor 20 Tahun 2016 tentang Merek dan Indikasi Geografis

Sebetulnya, perlindungan hak cipta hanya diterapkan pada komersialisasi ciptaan, yaitu karya yang mempunyai sifat khas dan menunjukkan keasliannya di ilmu pengetahuan, sastra atau seni. Jadi intinya, yang menjadi objek ialah ciptaan itu sendiri yang dijual melalui pengumuman dan perbanyakan. Sementara perlindungan merek memiliki tujuan untuk melindungi produk, baik berupa barang maupun jasa terhadap asosiasi yang salah mengenai sumber dari produk tersebut yang lalu akan melindungi produsen dan konsumen atas produk.

Dalam Undang-undang Nomor 15 Tahun 2001 Tentang Merek, yang diubah melalui Undang-undang Nomor 20 tahun 2016 tentang Merek dan Indikasi Geografis (selanjutnya disebut UU Merek dan Indikasi Geografis). Pasal 1 angka 1, merek adalah tanda yang dapat ditampilkan secara grafis berupa gambar, logo, nama, kata, huruf, angka, susunan warna, dalam bentuk 2 (dua) dimensi dan/atau 3 (tiga) dimensi, suara, hologram, atau kombinasi dari 2 (dua) atau lebih unsur tersebut untuk membedakan barang dan/atau jasa yang diproduksi oleh orang atau badan hukum dalam kegiatan perdagangan barang dan/atau jasa.

Hak cipta digunakan untuk melindungi ciptaan dari tindakan-tindakan yang melanggar hak eksekutif, baik hak ekonomi maupun hak moral atas sebuah 
ciptaan. Sedangkan hak merek digunakan untuk melindungi produk dari pemalsuan asosiasi oleh kompetitor yang bisa mengganggu penjualan serta reputasi produk tersebut.

Label merupakan hak dalam HKI, yang termasuk dalam hak cipta dan hak merek. Sebab label erat kaitannya dengan merek (karena dalam beberapa hal juga bersifat distinktif) adalah hak cipta. Dilihat dari segi nilai ekonomi maka hak atas merek (termasuk juga hak cipta) yang dikategorikan sebagai obyek kekayaan intelektual, yang dikenal dengan nama "hak kekayaan inteletual" (intellectual property rights).

Label halal sendiri digunakan sebagai alat informasi atau penanda apakah suatu produk pangan tersebut halal atau tidak. Oleh karena itu, apabila dikaitkan pada HKI maka label termasuk dalam katagori logo. Logo sendiri merupakan bagian dari Hak Cipta dan Merek yang berfungsi sebagai tanda pembeda. Sehingga logo atau label dapat dilindungi apabila didaftarkan dan dicatatkan sebagai merek.

Hal ini juga disampaikan oleh Kepala Subtansi Bidang Pelayanan Administarasi Hukum Umum dan Kekayaan Intelektual Direktorat Jenderal Kementrian Hukum dan HAM yang mengatakan bahwa :

"Proses pembuatan label halal pada produk pangan merupakan wewenang Majelis Ulama Indonesia yang disebut sebagai Pencipta dan dicatatkan oleh Diktorat Kekayaan Intelektual. Maka label halal itu sendiri sudah termasuk kategori Kekayaan Intelektual yang dilindungi oleh Undang - undang Hak Merek. Sebagai Kekayaan
Intelektual yang telah dicatatkan resmi dan disebut sebagai Surat Pencatatan Ciptaan yang memiliki nomor regristrasi No.C00200803046 dapat dilihat dengan jelas pada webside resmi dirjen haki menkumham www.dgip.go.id, sebagai Label Halal yang diterbitkan oleh Kementrian dan/atau lembaga terkait. Sehingga dapat disimpulkan bahwa label halal telah di lindungi oleh hak merek sebagaimana tercantum dalam Undang-Undang Nomor 20 tahun 2016 tentang Hak Merek dan Indikasi Geografis".

Berdasarkan UU Merek dan Indikasi Geografis tahun 2016 disebutkan bahwa logo termasuk dalam merek, sebagaimana ditegaskan pada Pasal 1 angka 1 mengenai pengertian merek. Selain itu, diatur juga pada Pasal 4 ayat (4) dan ayat (6) mengenai Syarat dan Tata Cara Permohonan Pendaftaran Merek. Dari uraian di atas, dapat disimpulkan bahwa label halal termasuk dalam kategori Merek.

Berdasarkan Peraturan Menteri Perdagangan No.67/MDAG/PER/11/2013 mengatakan bahwa, label adalah setiap keterangan mengenai barang yang berbentuk gambar, tulisan, kombinasi keduanya atau bentuk lain yang memuat informasi tentang barang dan keterangan pelaku usaha serta informasi lainnya sesuai dengan ketentuan peraturan perundangundangan yang berlaku. Sedankan label halal merupakan pencantuman tulisan atau pernyataan halal pada kemasan produk untuk menunjukkan bahwa produk yang dimaksud berstatus sebagai produk halal.

Label halal diperoleh setelah mendapatkan sertifikat halal. Sertifikat 
halal adalah suatu fatwa tertulis dari Majelis Ulama Indonesia (MUI) yang menyatakan kehalalan suatu produk sesuai dengan syariat Islam. Sertifikat halal ini merupakan syarat untuk mendapatkan ijin pencantuman label halal pada kemasan produk dari instansi pemerintah yang berwenang. Adapun yang dimaksud dengan produk halal adalah produk yang memenuhi syarat kehalalan sesuai dengan syariat Islam.

Syarat kehalalan suatu produk diantaranya: Tidak mengandung babi dan bahan yang berasal dari babi; Tidak mengandung bahan-bahan yang diharamkan. Seperti bahan-bahan yang berasal dariorgan manusia, darah, kotorankotoran, dan lain sebagainya; Semua bahan yang berasal dari hewan halal yang disembelih menurut tata cara syariat Islam; Semua tempat penyimpanan, tempat penjualan, pengolahan, tempat pengelolaan dan transportasinya tidak boleh digunakan untuk babi. Jika pernah digunakan untuk babi atau barang yang tidak halal lainnya terlebih dahulu harus dibersihkan dengan tata cara yang diatur menurut syariat Islam; Semua makanan dan minuman yang tidak mengandung khamar.

Aspek yang menjadi tinjauan dalam labelisasi halal yaitu:

Proses Pembuatan Proses pembuatan atau proses produksi perusahaan yang sudah menggunakan label halal hendaknya harus tetap menjaga hal-hal sebagai berikut:

1. Binatang yang hendak dibersihkan, binatang yang sudah mati setelah disembelih.

2. Bahan campuran yang digunakan dalam proses produksi tidak terbuat dari barang-barang atau bahan yang haram dan turunannya.
3. Air yang digunakan untuk membersihkan bahan hendaklah air mutlak atau bersih dan mengalir.

4. Dalam proses produksi tidak tercampur atau berdekatan dengan barang atau bahan yang najis atau haram.

Bahan Baku Utama Bahan baku produk adalah bahan utama yang digunakan dalam kegiatan proses produksi, baik berupa bahan baku, bahan setengah jadi maupun bahan jadi. Sedangkan bahan tambahan produk adalah bahan yang tidak digunakan sebagai bahan utama yang ditambahkan dalam proses teknologi produksi.

Bahan pembantu atau bahan penolong adalah bahan yang tidak termasuk dalam kategori bahan baku ataupun bahan tambahan yang berfungsi untuk membantu mempercepat atau memperlambat proses produksi termasuk proses rekayasa genetika dan radiasi pangan.

Efek Makanan halal tidak boleh terlepas dari tujuan syariat Islam, yaitu mengambil maslahat dan menolak madharat atau bahaya. Jika menurut kesehatan, suatu jenis makanan dapat membahayakan jiwa, maka makanan tersebut haram dikonsumsi. Sertifikasi dan labelisasi halal bertujuan untuk memberikan kepastian hukum dan perlindungan terhadap konsumen, serta meningkatkan daya saing produk dalam negeri dalam rangka meningkatkan pendapatan Nasional.

Label halal tidak selalu menjamin kehalalan produk yang berada dalam kemasan. Penyalahgunaan label halal juga sering dilakukan produsen-produsen "curang". Kecurangan berupa pengganti komposisi bahan setelah mendapatkan sertifikat halal atau memalsukan label halal pada produknya (bagi produsen yang belum 
memperoleh sertifikat halal dari BPJPH). Pemalsuan ini dilatarbelakangi beberapa kemungkinan, misalnya : 1) Sistem birokrasi yang terlalu prosedural. 2) Kontrol dari pemerintah atau pihak yang berwenang terlalu longgar. 3) UndangUndang yang lemah.

Karakteristik produk yang berlabel halal yaitu :

1. Tidak mengandung babi atau produk-produk yang berasal dari babi serta tidak menggunakan alkohol sebagai ingridient yang sengaja ditambahkan.

2. Daging yang digunakan berasal dari hewan halal yang disembelih menurut tata cara syariat Islam.

3. Semua bentuk minuman yang tidak beralkohol.

4. Semua tempat penyimpanan, tempat penjualan, pengolahan, tempat pengelolaan dan tempat transportasi tidak digunakan untuk babi atau barang tidak halal lainnya, tempat tersebut harus terlebih dahulu dibersihkan dengan tata cara yang diatur menurut syari'at Islam.

Label merupakan bagian dari suatu produk yang menyampaikan informasi mengenai produk dan penjual. Sebuah label bisa merupakan bagian dari kemasan atau pula etiket (tanda pengenal) yang dicantelkan pada produk. Karakterisktik label terbagi ke dalam 3 klasifikasi yaitu :

Brand Label, yaitu merek yang diberikan pada produk atau dicantumkan pada kemasan.

Descriptive Label, yaitu label yang memberikan informasi objektif mengenai penggunaan, konstruksi/pembuatan, perhatian/perawatan, dan kinerja produk, serta karakteristik-karakteristik lainnya yang berhubungan dengan produk.

Grade Label, yaitu label yang mengidentifikasikan penilaian kualitas produk (product's judged quality) dengan suatu huruf, angka, atau kata.

Label memiliki 3 fungsi utama yaitu

1) mengidentifikasikan produk atau merek

2) menentukan kelas produk

3) menjelaskan produk yaitu siapa pembuatnya, kapan, dimana, apa isinya.

Dari ketiga karakteristik label di atas, maka label halal termasuk dalam klasifikasi Descriptive Label. Sebab label halal yang diterbitkan Badan Penyelenggaraan Jaminan Produk Halal (BPJPH) bersama Majelis Ulama Indonesia (MUI) berfungsi sebagai media informasi atau penanda bagi umat muslim mengenai halal atau tidaknya suatu produk pangan.

Penyelenggara JPH adalah BPJPH yang harus dibentuk paling lambat tiga tahun sejak UU JPH diundangkan. Namun sebelum BPJPH dibentuk, MUI tetap menjalankan tugasnya di bidang sertifikasi halal sampai dengan BPJPH terbentuk. Artinya LPPOM-MUI masih memegang peranan dalam penerbitan sertifikat halal sebelum terbentuknya BPJPH. BPJPH memiliki kewenangan untuk, yaitu:

1. merumuskan dan menetapkan kebijakan $\mathrm{JPH}$,

2. menetapkan norma, standar, prosedur, dan kriteria JPH,

3. menerbitkan dan mencabut sertifikat halal dan label halal pada produk.

4. melakukan registrasi sertifikat halal pada produk luar negeri,

5. melakukan sosialisasi, edukasi, dan publikasi produk halal,

6. melakukan akreditasi terhadap LPH, 
7. melakukan registrasi auditor halal

8. melakukan pengawasan terhadap JPH

9. melakukan pembinaan auditor halal, dan

10. melakukan kerja sama dengan lembaga dalam dan luar negeri di bidang penyelenggaraan JPH.

Menurut ketentuan LPPOM-MUI dalam Panduan Jaminan Halal, Sertifikasi Halal adalah suatu proses untuk memperoleh sertifikat halal melalui beberapa tahap untuk membuktikan bahwa bahan, proses produksi, dan Sistem Jaminan Halal memenuhi standar LPPOM-MUI.

Sertifikat halal adalah fatwa tertulis MUI yang menyatakan kehalalan suatu produk sesuai dengan syari'at Islam. Sertifikat halal ini merupakan syarat untuk mencantumkan label halal pada kemasan produk, dengan tujuan memberikan kepastian kehalalan suatu produk pangan, obat-obatan dan kosmetika, sehingga dapat menenteramkan batin yang mengkonsumsinya. Sertifikat halal suatu produk diterbitkan setelah diputuskan dalam sidang Komisi Fatwa MUI yang sebelumnya berdasarkan proses audit yang dilakukan oleh LPPOM-MUI. Sertifikat Halal ini merupakan syarat untuk mendapatkan ijin pencantuman label halal pada kemasan produk dari instansi pemerintah yang berwenang.

\section{Pengertian LPPOM-MUI}

Menyadari tanggung jawabnya untuk melindungi masyarakat, maka Majelis Ulama Indonesia mendirikan Lembaga Pengkajian Pangan, Obat-obatan, dan Kosmetika atau lebih dikenal sebagai LPPOM-MUI. Lembaga ini didirikan sebagai bagian dari upaya untuk memberikan ketenteraman batin umat, terutama dalam mengkonsumsi pangan, obat dan kosmetika. Lembaga ini didirikan atas keputusan Majelis Ulama Indonesia (MUI) berdasarkan surat keputusan nomor 018/MUI/1989, pada tanggal 26 Jumadil Awal 1409 Hijriah atau 6 Januari 1989.

LPPOM-MUI telah memberikan peranannya dalam menjaga kehalalan produk-produk yang beredar di masyarakat. Pada awal-awal tahun kelahirannya, LPPOM-MUI berulang kali mengadakan seminar, diskusi-diskusi dengan para pakar, termasuk pakar ilmu Syari'ah, dan kunjungan-kunjungan yang bersifat studi banding serta muzakarah. Hal ini dilakukan untuk mempersiapkan diri dalam menentukan standar kehalalan dan prosedur pemeriksaan, sesuai dengan perkembangan ilmu pengetahuan dan kaidah agama. Pada awal tahun 1994, barulah LPPOM-MUI mengeluarkan sertifikat halal pertama yang sangat didambakan oleh konsumen maupun produsen, dan sekarang dapat dirasakan manfaatnya oleh masyarakat.

\section{Status dan Kewenangan LPPOM-MUI}

Sertifikasi halal adalah fatwa tertulis. Sehingga, harus diberikan oleh lembaga yang memiliki kompetensi memberikan fatwa, dan yang kompeten memberikan fatwa adalah MUI. Sertifikat halal adalah fatwa tertulis yang menjelaskan status kehalalan suatu produk. Fatwa ini harus diterbitkan oleh lembaga yang memiliki kompetensi untuk menetapkan fatwa yaitu MUI. Sertifikasi halal yang dilakukan MUI adalah cara masyarakat untuk mengkoreksi atau mengawasi produsen sebelum produknya beredar di masyarakat karena masyarakat tidak berwenang mengawasi produk yang beredar. Status dan kedudukan hukum LPPOM-MUI adalah sebagai satu- 
satunya lembaga yang mempunyai kewenangan dalam mengeluarkan sertifikasi halal di Indonesia.

Dalam melaksanakan wewenang sebagaimana dimaksud dalam Pasal 6, BPJPH bekerja sama dengan: a) kementerian dan/atau lembaga terkait; b) LPH; dan c) MUI.

Pasal 27 (1) UU JPH, Pelaku Usaha yang tidak melakukan kewajiban sebagaimana dimaksud dalam Pasal 25 dikenai sanksi administratif berupa: a) peringatan tertulis; b) denda administratif; atau c) pencabutan Sertifikat Halal.

Pelaku Usaha yang tidak melakukan kewajiban sebagaimana dimaksud dalam Pasal 26 ayat (2) UU JPH, dikenai sanksi administratif berupa: a) teguran lisan; b) peringatan tertulis; atau c) denda administratif.

Konsumen sebagai pengguna produk, mendapatkan perlindungan hukum melalui Undang - Undang Nomor 08 Tahun 1999 tentang Perlindungan Konsumen sehingga konsumen yang merasa dirugikan akibat produk dapat menuntut pelaku usaha tersebut. Didalam Pasal Pasal 19 berbunyi :

1) Pelaku usaha bertanggung jawab memberikan ganti rugi atas kerusakan, pencemaran, dan atau kerugian konsumen akibat mengkonsumsi barang dan atau jasa yang dihasilkan atau diperdagangkan.

2) Ganti rugi sebagaimana dimaksud pada ayat (1) dapat berupa pengembalian uang atau penggantian barang dan/atau jasa yang sejenis atau setara nilainya, atau perawatan kesehatan dan/atau pemberian santunan yang sesuai dengan ketentuan peraturan perundang-undangan yang berlaku.

3) Pemberian gantirugi dilaksanakan dalam tenggang waktu 7 (tujuh) hari setelah tanggal transaksi.

4) Pemberian ganti rugi sebagaimana dimaksud pada ayat (1) dan ayat (2) tidak menghapuskan kemungkinan adanya tuntutan pidana berdasarkan pembuktian lebih lanjut mengenai adanya unsur kesalahan.

Maka jika terjadi pemalsuan atau pelanggaran terhadap label halal yang digunakan pada produk pangan yang bersertifikat halal, maka BPJPH selaku penerbit sertifikasi halal dapat memberikan sanksi administratif kepada pelaku usaha berupa peringatan tertulis; denda administratif; atau pencabutan Sertifikat Halal. Sedangkan apabila konsumen merasa dirugikan akibat adanya pelanggaran atau pemalsuan terhadap label halal, maka konsumen dapat menuntut ganti rugi kepada pelaku usaha.

Pasal 10 ayat (1) Setiap orang yang memproduksi atau memasukkan pangan yang dikemas ke dalam wilayah Indonesia untuk diperdagangkan dan menyatakan bahwa pangan tersebut halal bagi umat Islam, bertanggung jawab atas kebenaran pernyataan tersebut dan wajib mencantumkan keterangan atau tulisan halal pada label. (2) Pernyataan tentang halal sebagaimana dimaksud pada ayat (1), merupakan bagian yang tidak terpisahkan dari label. Penjelasan Pasal 10 ayat (1) Pencantuman keterangan halal atau tulisan "halal" pada label pangan merupakan kewajiban apabila pihak yang memproduksi dan atau memasukan pangan kedalam wilayah Indonesia menyatakan (mengklaim) bahwa produknya halal bagi 
umat Islam. Penggunaan bahasa atau huruf selain bahasa Indonesia dan huruf Latin, harus digunakan bersamaan dengan padanannya dalam bahasa Indonesia dan huruf Latin. Keterangan tentang kehalalan pangan tersebut mempunyai arti yang sangat penting dan dimaksudkan untuk melindungi masyarakat yang beragama Islam dari mengkonsumsi pangan yang tidak halal (haram). Kebenaran suatu pernyataan halal pada label pangan tidak hanya dibuktikan dari segi bahan baku, bahan tambahan pangan, atau bahan bantu yang digunakan, tetapi harus pula dibuktikan dalam proses produksinya.

Pasal 11 (1) Untuk mendukung kebenaran pernyataan halal sebagaimana dimaksud dalam Pasal 10 ayat (1), setiap orang yang memproduksi atau memasukkan pangan yang dikemas kedalam wilayah Indonesia untuk diperdagangkan, wajib memeriksakan terlebih dahulu pangan tersebut pada lembaga pemeriksa yang telah diakreditasi sesuai dengan ketentuan peraturan perundangundangan yang berlaku. (2) Pemeriksaan sebagaimana dimaksud pada ayat (1) dilaksanakan berdasarkan pedoman dan tata cara yang ditetapkan oleh Menteri Agama dengan memperhatikan pertimbangan dan saran lembaga keagamaan yang memiliki kompetensi di bidang tersebut.

Penjelasan Pasal 11 ayat

Pencantuman tulisan halal pada dasarnya bersifat sukarela. Namun setiap orang yang memproduksi dan atau memasukkan pangan kedalam wilayah Indonesia untuk diperdagangkan menyatakannya sebagai produk yang halal, sesuai ketentuan bahwa ia wajib mencantumkan tulisan halal pada label produknya.
Sanksi berupa peringatan tertulis diberikan pada saat diketahui adanya unsur yang tidak dipenuhi oleh pelaku usaha mengenai produk pangan halal yang diterbitkan mengindikasikan bahwa produk tersebut tidak halal. Selain peringatan tertulis, sanksi kedua yaitu berupa saksi denda adminitatif, sanksi ini diberikan apabila pelaku usaha telah diperingatkan melalui peringatan tertulis namun tetap tidak menindakan/melaksanakan peringatan tersebut maka akan dikenakan denda adminitratif berupa bagi pelaku usaha dilarang memproduksi dan/atau memperdagangkan barang dan/atau jasa yang tidak mengikuti ketentuan berproduksi secara halal, sebagaimana pernyataan "halal" yang dicantumkan dalam label. Sanksi bagi pelaku usaha yang melanggar ketentuan dalam pasal 62 ayat (1) Undang Undang Perlindungan Konsumen adalah dipidana dengan pidana penjara paling lama 5 (lima) tahun atau pidana denda paling banyak Rp 2.000.000.000,00 (dua miliar rupiah). Kemudian saksi ketiga yang diberikan yaitu pencabutan sertifikat halal pada produk yang di produksi sehingga produk tersebut tidak dapat lagi dijual atau di pasarkan.

\section{Kesimpulan Dan Saran}

\section{Kesimpulan}

Berdasarkan uraian bab-bab terdahulu maka dapat disimpulkan sebagai berikut :

1. Label halal yang diterbitkan oleh Badan Penyelenggaraan Jaminan Produk Halal (BPJPH) digunakan sebagai alat informasi atau penanda apakah suatu produk pangan tersebut halal atau tidak. Menurut Hak Kekayaan Intelektual, label halal termasuk dalam kategori logo. Logo sendiri merupakan bagian 
dari Hak Cipta dan Merek yang berfungsi sebagai tanda pembeda. Sehingga logo atau label halal dapat dilindungi apabila dicatatkan sebagai merek. Istilah Label tidak diatur secara tersurat dalam UUHC maupun UU Merek dan Indikasi Geografis. Menurut Pasal 65 UUHC terbaru (Undangundang Nomor 28 Tahun 2014) pencatatan ciptaan tidak dapat dilakukan terhadap seni lukis berupa logo atau tanda pembeda yang digunakan sebagai merek dalam perdagangan barang/jasa, yang digunakan sebagai lambang organisasi atau badan hukum. Sehingga logo atau label halal dapat dilindungi apabila didaftarkan sebagai merek untuk kepentingan komersial. Berdasarkan UU Merek dan Indikasi Geografis tahun 2016 disebutkan bahwa logo termasuk dalam merek, sebagaimana ditegaskan pada Pasal 1 angka 1 mengenai pengertian merek. Selain itu, diatur juga pada Pasal 4 ayat (4) dan ayat (6) mengenai Syarat dan Tata Cara Permohonan Pendaftaran Merek. Dari uraian di atas, dapat disimpulkan bahwa label halal termasuk dalam kategori Merek.

2. Karakteristik label terbagi dalam 3 klasifikasi yaitu : Brand Label yaitu merek yang diberikan pada produk atau dicantumkan pada kemasan; Descriptive Label yaitu label yang memberikan informasi objektif mengenai penggunaan, konstruksi/pembuatan, perhatian/perawatan, dan kinerja produk, serta karakteristik karakteristik lainnya yang berhubungan dengan produk; Grade Label yaitu label yang mengidentifikasikan penilaian kualitas produk (product's judged quality) dengan suatu huruf, angka, atau kata. Dari ketiga karakteristik label di atas, maka label halal termasuk dalam klasifikasi Descriptive Label yang dapat dilihat dalam Pasal 1 angka 1 UndangUndang Nomor 20 Tahun 2016 tentang Merek dan Indikasi, Merek adalah tanda yang dapat ditampilkan secara grafis berupa gambar, logo, nama, kata, huruf, angka, susunan warna, dalam bentuk 2 (dua) dimensi dan/atau 3 (tiga) dimensi, suara, hologram, atau kombinasi dari 2 (dua) atau lebih unsur tersebut untuk membedakan barang dan/atau jasa yang diproduksi oleh orang atau badan hukum dalam kegiatan perdagangan barang dan/atau jasa. Sebab label halal yang diterbitkan Badan Penyelenggaraan Jaminan Produk Halal (BPJPH) bersama Majelis Ulama Indonesia (MUI) berfungsi sebagai media informasi atau penanda bagi umat muslim mengenai halal atau tidaknya secara mutlak suatu produk pangan yang banyak beredar dimasyarakat.

3. Peran Badan Penyelenggaraan Jaminan Produk Halal (BPJPH) bekerja sama dengan kementerian dan/atau lembaga terkait, LPH dan MUI, jika terjadi pemalsuan terhadap label halal maka BPJPH hanya dapat memberikan tindakan kepada pelaku usaha berupa sanksi administratif yaitu peringatan tertulis, denda administratif atau pencabutan Sertifikat Halal. Sedangkan konsumen yang merasa dirugikan akibat hal tersebut dapat menuntut pelaku usaha berdasarkan undang-undang perlindungan konsumen. 
Saran

1. Kepada pemerintah yaitu Presiden dan DPR agar membuat peraturan perundang-undangan agar memperbaharui undang-undang yang sudah ada khususnya mengenai label halal. Agar ketiga Undang-Undang yaitu Undang-Undang Nomor 28 Tahun 2014 Tentang Hak Cipta, UndangUndang Nomor 20 Tahun 2016 Tentang Merek dan Indikasi Geografis, UndangUndang Nomor 33 Tahun 2014 Tentang Jaminan Produk Halal maka masingmasing peraturan tersebut saling melengkapi agar terjadi keharmonis dan selaras dalam penyebutan istilah Label atau Logo.

2. Kepada Dirjen Kekayaan Intelektual yang berwenang untuk melakukan pencatatan terhadap Label Halal seharusnya memberikan pengarahan kepada Majelis Ulama Indonesia untuk mencatatkan kembali label halal pada Dirjen Kekayaan Intelektual Hukum dan Hak Asasi Manusia untuk dicatatkan kembali sebagai Hak Merek bukan hak Cipta.

3. Kepada pemerintah sebaiknya lebih memberikan kepastian terkait lembaga mana yang berhak dan berwenang untuk memberikan sertifikasi dan labelisasi halal dalam suatu produk sehingga masyarakat khususnya yang beragama Islam lebih mendapatkan kepastian hukum terkait produk mana yang dapat dikonsumsi dan produk mana yang tidak dapat dikonsumsi. Sehingga menimbulkan ketenangan bagi masyarakat khusunya yang beragama Islam.

4. Kepada masyarakat agar lebih teliti dan berhati-hati dalam memilih produk halal, agar lebih teliti dalam memilih produk halal yang memang jelas diterbitkan oleh pihak yang berwenang untuk produk halal tersebut. 